\title{
Urolithiasis and Ayurveda
}

\author{
Dr Avinash Shankar, MD (Internal medicine); DNB (E\&M), PhD \\ Postgraduate in Endocrinology \& Metabolism (AIIMS-Delhi), Chairman, National Institute of Health \& \\ Research, Warisaliganj (Nawada) Bihar India \\ Dr Amresh Shankar, BAMS (BRABU); MBA (HM) \\ Medical Officer, Bihar State Health Services, Director (Hon), Aarogyam Punarjeevan, Ram Bhavan, Ara \\ Garden Road,Jagdeopath ,Baily Road, Patna 14,Bihar 800014
}

\section{Dr Anuradha Shankar BAMS (BRABU)}

Director, Centre For Research in Indigenous Medicine, Warisaliganj (Nawada), Bihar 805130

*Corresponding Author: Dr Avinash Shankar, Postgraduate in Endocrinology \& Metabolism (AIIMSDelhi), Chairman, National Institute of Health \& Research, Warisaliganj (Nawada) Bihar India

\begin{abstract}
Urolithiasis, a world wide problem rising in geometric progression is considered to be solely due to changed dietary habit, dietary constituents and life style. Recurrence even on surgical removal or lithotripsy, the only way is to ensure medical expulsion of stone and bioregulated mineral biokinetics , assessment of indigenous herb active constituent i.e.- Carica papaya (root) and Piper nigrum (berries) extract daily orally in early morning proved worth in expelling the stone per urethra from various sites of $K U B$ and check recurrence of urolithiasis and achieved grade I clinical cure in $97 \%$ cases without any adversity or recurrence in 5 yrs of rigrous follow up .
\end{abstract}

Keywords: Urolithiasis, active constituents, medical expulsion, biokinetics, bioregulation

\section{INTRODUCTION}

Urolithiasis is progressively increasing and its incidence range between 120-140/10 lakh population with male: female ratio of $3: 1$,but these days $10-12 \%$ population is affected in industrialized country ${ }^{1}$ and commonly affected age group is $20-40$ yrs and male: female constitution is changed from 1.7:1 to 1.3:1 The prevalence of life time risk is increasing and 50\% patients have recurrence within next 10 years . ${ }^{2,3}$

As per American Urological Assocaition (AUA) Stones measuring $<5 \mathrm{~mm}$ passes spontanceously in majority (98\%) cases while only $25-62 \%$ cases with stones measuring $5-10 \mathrm{~mm}$ passes of their own and required time ranges from $8-22$ days ${ }^{4}$.

Progressive increase in the incidence of Calcium oxalate, phosphate calculi of the upper urinary tract during the $20^{\text {th }}$ century is due to changed dietary composition posing an increase in urinary solute load ,not only due to altered nutrition resulting from use of irrational food constituent ,preservation and storage of food remain full of noxious chemical use which not only generate non dietary constituent but also generate some enzyme inhibitor to compete with various body enzyme intends altered ionic exchange and urine crystallization .In addition recurrent urinary tract infection due to increased mis use of broad spectrum high antibiotics, self medication and declined water intake predispose for urolithiasis due to presence of urea splitting bacteria .In addition carbohydrate rich dietary habit increases urinary calcium and magnesium excretion., 6

Considering the efficacy of therapeutics in vogue and option for surgical removal Or lithotripsy is not only a costly affair but also encumbrance due to recurrence ${ }^{7,8,9}$. Treatment option for patients urinary stone been advanced significantly over the past few decades i.e.- Extracorporeal shock wave lithotripsy (ESWL), Percutaneous nephro lithotomy (PCNL), Retrograde interarenal surgery (RIRS) and Laproscopic uretero lithotomy but recurrence even after surgical intervention poses threat, for which medical expulsion therapy remain ${ }^{10,11}$ choice in the context an indigenous composit having both litholytic and diuretic effect been evaluated in patients of urolithiasis . None secure litholysis but facilitate removal of existing urinary stones only . 
Thus to check recurrence and alleviate clinical presentation ,facilitate expulsion of stone ,check urine infection, prevent crystallization, a clinical evaluation of Watery extract of Carica papaya (root) and Piper nigrum (berries) early in the morning orally been evaluated at RA.Hospital \& Research Centre in association with Centre For Indigenous Medicine \& Research, Warisaliganj (Nawada) Bihar 805130 ,India .

\section{MATERIAL \& MethodS}

Patients of urolithiasis and abdominal colic (Ureteric colic Or Renal colic) attending medical OPD of RA. Hospital \& Research Centre, Warisaliganj (Nawada) Bihar during April 2012 t0 August 2013 were selected and evaluated by Centre For Indigenous Medicine and Research for therapeutic efficacy and safety profile.

Index for selection of patients:

- Agonizing abdominal pain in the loin ,supra pubic region and back

- Frequency of micturation and gritting sensation

- Any history of hematuria or passage of crystal per urethra

- Any history of surgery or lithotripsy for stone in KUB

Selected patients(Or parent of the patient)were interrogated, examined and investigated for presence of uroliths i.e.- urine for crystals, X-ray KUB,,IVP,USG for KUB to ascertain the presence or localization of stone in the kidney or urinary pathway, its size and sequelae.

In addition serum creatitinine, serum calcium, serum uric acid and blood urea been assessed to adjudge the safety profile in terms of hemato hepato renal status .

All the patients of urolithiasis without consequent adversity affecting renal function been considered for evaluation of Clinical efficacy of watery extract of Carica papaya (root) and Piper nigrum (berries) in empty stomach daily for 3 months and patients were followed during the therapy to observe the -

- Relief of clinical presentation

- Any adverse presentation

- History of passage of crystal per urethra

- Any disease related sequel

During post therapy patients were followed up for 3 years and observed for -

- Any recurrence of presentation

- Any untoward effects

For the purpose a follow up card been issued to every patients or parent or Medical social worker covering the patients group and been advised to enter all the details or observation by the patients Or parent i.e.- passage of crystal, blood in urine, agonizing pain during micturation ,inability to pass urine Or retention of urine with distended bladder .

Pre, post and during the therapy each patient's renal function been duly assessed to adjudge the safety profile of the trial drug composite.

Based on observation clinical response was graded as-

\begin{tabular}{|l|l|}
\hline Grades of clinical efficacy & Characteristics \\
\hline Grade I & $\begin{array}{l}\text { Complete relief of pain in abdomen } \\
\text { Absence of crystals in urine and USG with or without history of passing } \\
\text { crystals per urethra and without any recurrence and untoward effects }\end{array}$ \\
\hline Grade II & $\begin{array}{l}\text { Complete relief of pain and other presentation Absence of crystal in USG } \\
\text { but presence of crystal flecks in urine Without any untoward effects and } \\
\text { recurrence during follow up }\end{array}$ \\
\hline Grade III & $\begin{array}{l}\text { Relief of pain with frequent recurrence, dysuria,presence of crystals in the } \\
\text { urine but of very much reduced size, No untoward effects }\end{array}$ \\
\hline Grade IV & No response \\
\hline
\end{tabular}




\section{OBSERVATION}

Among the selected patients 59\% were male and $41 \%$ female of age group 5-35 years .11\% patients were of age group $<5$ years , $18 \%$ of age group 5-10 years while $17 \%$ were of 30 -35 years (T-1) $20 \%$ patients were suffering from $<1$ year while $8 \%$ from $>5$ years (Bar diagram )

$36 \%$ patients had history of passing crystal per urethra, 57\% recurrent urinary tract infection and $20 \%$ with pain ful hematuria (T- 3)

Out of all 56\% were newly detected case of uroliths while $13 \%$ and $65 \%$ were cases of uroliths removal by surgery and lithotripsy respectively. (T-4)

95\% patients had clinical relief within 48 hours of therapy and had complete relief of the presenting feature while $13 \%$ had marked improvement in 15 days of therapy.

$80 \%$ patients revealed passage of uroliths through urine after 45 days of therapy and after 2 months 97\% patient's Ultrasonography for KUB shows absence of stone while 3\% show marked regression of size and change in site of stone.

No patient revealed any alteration in hematological, hepatic and renal function Or any other side effects Or recurrence of presentation during 2 years of post therapy follow up.

97\% patients had Grade I clinical response while 3\% Grade II response.

\section{DisCUSSIONS}

In India incidence of urolithiasis varies regionally and in spite of available measures for Urolith removal i.e. Surgery, lithotripsy, Short Wave Diathermy (SWD), Endoscopic lazor surgery9, recurrence is very rampant due to changed minerals bio kinetics as a result of changed dietary strategy 12

In addition various indigenous compote formulation are in vogue and posses proved efficacy and no ancient literature affirm the use of common house hold plant Carica papaya root extract in management of urolithiasis and present study affirm its high clinical efficacy in stone removal with high safety profile ,this clinical supremacy can be explained as $-{ }^{13}$

Lithotriptic effect of Carica papaya active constituent Gluco hydrolase botanic acid, Cryptoglavin as a potent anti bacterial constituent ,Pergunodiene ,isopiperolene and trachiene of Piper nigrum effective against common urinary pathogen Escheresia coli ,Alloxanthine, Cis valloxanthine of Carica papaya acts as a diuretic and helps expel the calculi. Musculo relaxant action of Piperin relieves abdominal colic synergized with local anaesthatic action of Carpain, Piperidine acts as an anti oxidant, prevent aggregation of urinary flecks in the urinary path way. ${ }^{14}$

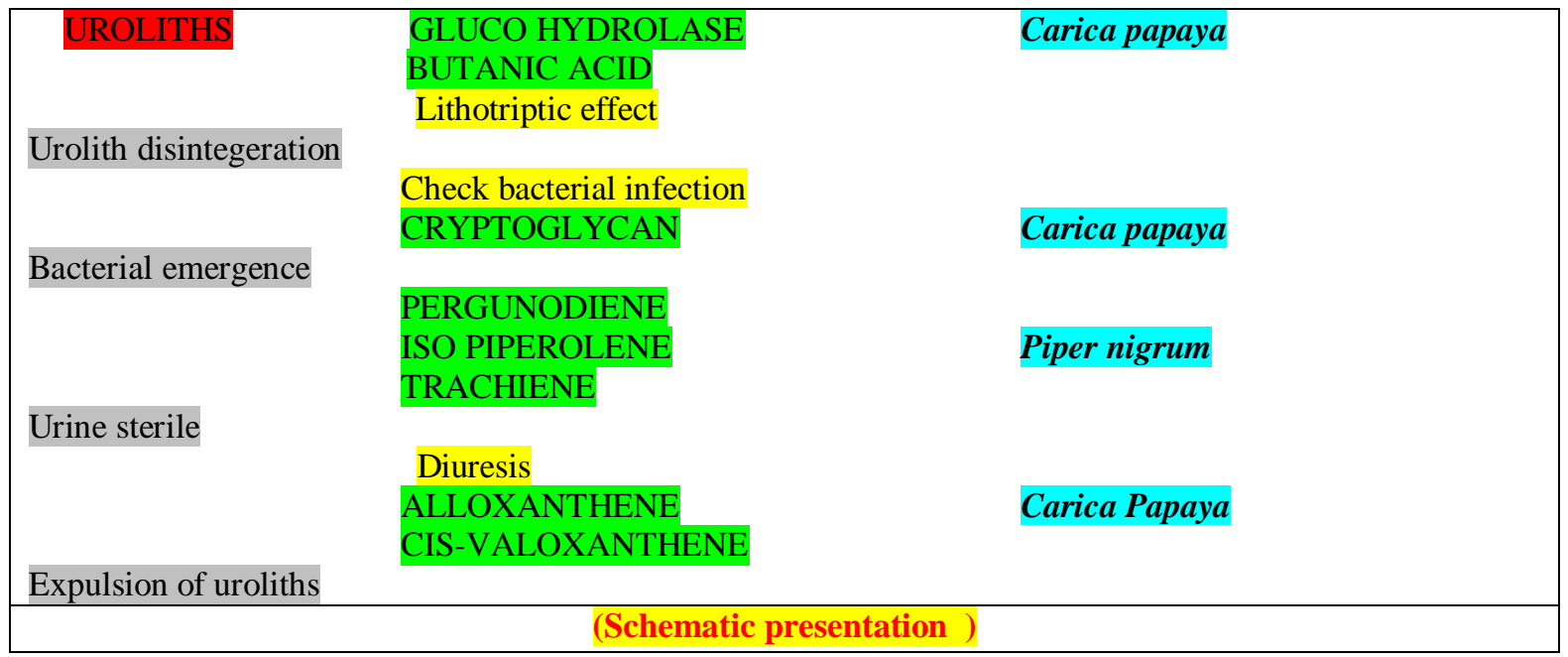

$\alpha$-adreno receptor antagonist, calcium channel blocker and Phosphodiestrase 5 relaxes the ureteric smooth muscles and reduces uretral contraction or spasm, inhibit peristalsis and facilitate calculi elimination . 
Stimulation of $\alpha$-adrenergic receptor at the ureter increases force of ureteric contraction leads to increased frequency of ureteric peristalsis.

Blockade of receptor inhibit basal tone $--\rightarrow$ decreases peristaltic amplitude and frequency $---\rightarrow$ decreases intra luminal pressure ------ $\rightarrow$ increased rate of fluid transport $---\rightarrow$ increased calculi expulsion Distal part of ureter constitute $\alpha 1 \mathrm{~A}$ and $\alpha 1 \mathrm{D}$ adrenergic receptor are more densely located.

\begin{tabular}{|l|l|}
\hline Piperine $-----\rightarrow$ muscle relaxation & \\
Carpaine----- $\rightarrow$ local anaesthetic & Relieves Spasm $---\rightarrow$ Relieves Colic \\
Piperidine -------- Anti oxidant $-\rightarrow$ Prevent aggregation of Urine flecks $--\rightarrow$ check urolithiasis
\end{tabular}

\section{CONCLUSION}

Watery extract of Carica papaya root and Piper nigrum berry wit dietary restriction and encouraged water intake ensure expulsion of uroliths, check formation or aggregation of sands in both fresh or old or relapse cases after stone removal.

Table1. Distribution of patients as per age and sex

\begin{tabular}{|l|l|l|l|l|}
\hline \multirow{2}{*}{$\begin{array}{l}\text { Age group } \\
\text { (in years) }\end{array}$} & Number of patients & Fale & Female & Total \\
\hline$<5$ & 32 & 21 & 53 & 11 \\
\hline $5-10$ & 52 & 40 & 92 & 18 \\
\hline $10-15$ & 42 & 30 & 72 & \\
\hline $15-20$ & 48 & 29 & 77 & \\
\hline $20-25$ & 38 & 22 & 60 & \\
\hline $25-30$ & 36 & 24 & 60 & 17 \\
\hline $30-35$ & 50 & 38 & 88 & \\
\hline
\end{tabular}

Table2. Pie diagram showing male female composition

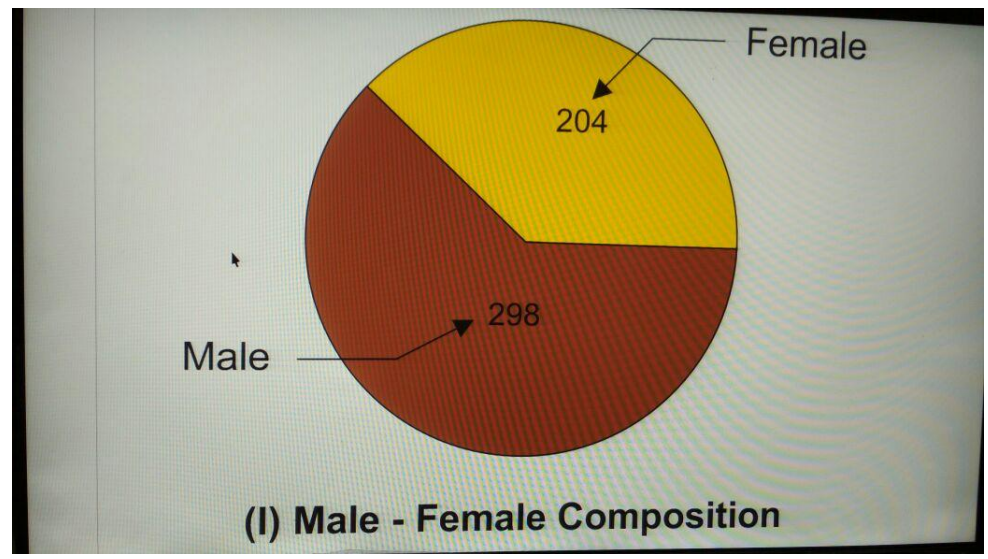

Table3. Bar diagram for duration of illness

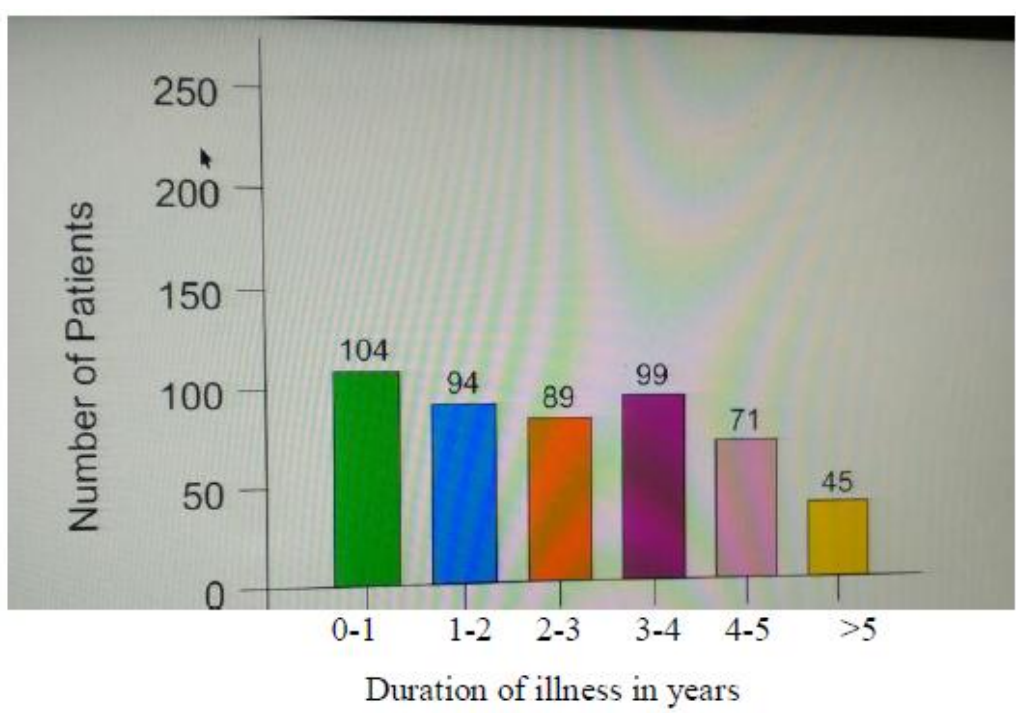


Table4. Distribution of patients as per presenting features

\begin{tabular}{|l|l|l|}
\hline Presenting features & Number of patients & Percentage \\
\hline Agonising abdominal pain & 502 & \\
\hline Frequency of micturation & 502 & \\
\hline Gritting sensation during micturation & 490 & 98 \\
\hline Retention of urine & 234 & 47 \\
\hline Backache & 282 & 56 \\
\hline Painful micturation & 480 & 96 \\
\hline Passage of urolith & 182 & 36 \\
\hline Painful hematuria & 098 & 20 \\
\hline Recurrent pyrexia & 288 & 57 \\
\hline
\end{tabular}

Table5. Showing distribution of patients as per location of stone

\begin{tabular}{|l|c|}
\hline Site of calculi & Number of patients \\
\hline Renal pelvis & 309 \\
\hline Ureter : & 106 \\
Upper part & 087 \\
Lower part & \\
\hline
\end{tabular}
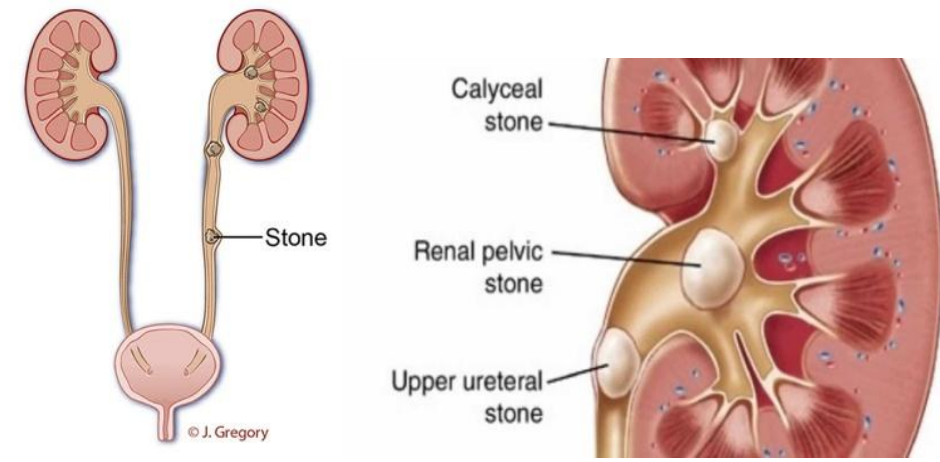

Table6. Distribution of patients as per their therapeutic status

\begin{tabular}{|l|c|c|}
\hline Therapeutic measures & Number of patients & Percentage \\
\hline Newly detected cases & 282 & 56 \\
\hline Treated medically with recurrence & 088 & 18 \\
\hline Treated surgically with recurrence & 064 & 13 \\
\hline Lithoripsy with recurrence & 034 & 6.5 \\
\hline Non conventional measures & 34 & 6.5 \\
\hline
\end{tabular}

Table7. Outcome of the study

\begin{tabular}{|l|c|}
\hline Particulars & Number of patients \\
\hline Relief in presenting complaints \\
\hline Complete & 488 \\
Marked & 014 \\
Passage of uroliths per urethra & 403 \\
\hline Ultra sono graphy for KUB \\
\hline Absence of crystals \\
Decline in size and descend of & 488 \\
crystal & 014 \\
\hline Safety profile : & \\
\hline Blood urea & 488 \\
Unchanged & 014 \\
Mild rise & \\
Serum Creatinine & 502 \\
\multicolumn{1}{||}{ < 1.5 mg } & None \\
\hline Clinical response grade & $97 \%$ \\
\hline Grade I & $03 \%$ \\
Grade II
\end{tabular}




\section{REFERENCES}

[1] Johnson CM, Wilson DM,O' Fallon WM, Malek RS, Kurland LT, Renal stone epidemiology : A 25 years study in Rochester, Minnesota ,Kidney Int 1979:16:624-31

[2] Soucie JM, Coates RJ, McClellan W, Austin H, Thun M, Relation between geographic variability in Kidney stones ,prevalence and risk factors for stones . Am. J.Epidemiology 1996:143:487-95

[3] Pak CY, Kidney stones ,Lancet 1998:351:1797-801

[4] Miller OF, Kane CJ Time to stone passage for observed ureteral calculi , a guide for patient education ,J urol 1999; 162:688-90

[5] Curhan GC, Willett WC, Knight EL, Stamfer MJ, Dietary factors and the risk of incident kidney stones in younger women : Nurses Health study II, Arch. Intern Med.204:164:885-91

[6] Taylor EN, Stamfer MJ ,Curhan GC, Dietary factors and the risk of incident kidney stones in men, new insights after 14 years of follow up ,J Am.Soc.Nephrol.2004;15:325-32

[7] Portis AJ, Sundaram CP, Diagnosis and initial management of kidney stones , Am Fam Physician 2001;63:1329-38

[8] Tiselius HG,Ackermann D,Alken P, etal Guidelines on urolithiasis, Eur Urol 2001;40:362-71

[9] Turk C,Knoll T,Petrik A,Straub M,Seitz C, Guidelines on Urolithiasis

[10] Singh A, Alter HJ, Littlepage A, A systematic review of medical therapy to facilitate passage of ureteral calculi, Ann Emerg. Med 2007;50:252-63

[11] Healy KA,Ogan K,Non surgical management of Urolithiasis ,an overview of expulsive therapy ,J.Endourol.2005;19:759-67

[12] Hubner WA, Irby P, Stoller ML, Natural history and current concepts for the treatment of small ureteral calculi .Eur Urol 1993;24:172-6

[13] Shankar A; Pharmacokinetics of active ingredients of constituent herb , Pharmacological basis of indigenous therapeutics, Bhalani publication House ,Mumbai $1^{\text {st }}$ Edition

Citation: A. Shankar et al., "Urolithiasis and Ayurveda", International Journal of Clinical Chemistry and Laboratory Medicine (IJCCLM), vol. 3, no. 4, pp. 1-6, 2017. http://dx.doi.org/10.20431/2455-7153.0304001

Copyright: (C) 2017 Authors. This is an open-access article distributed under the terms of the Creative Commons Attribution License, which permits unrestricted use, distribution, and reproduction in any medium, provided the original author and source are credited. 